\title{
A CRITICAL EVALUATION OF FDI IN DEFENCE IN INDIA: REQUIREMENT, TRENDS AND FORECASTS
}

\author{
A Shridhar \\ Research Scholar, Osmania University, \\ Hyderabad, India
}

\begin{abstract}
Foreign Direct Investment (FDI) is defence is seen as a major source of non-debt financial resource, a means of achieving technical know-how and employment generation and hence the FDI limits in defence have been gradually liberalised. While, FDI in defence is capped at $49 \%$ approvals under the automatic route without government, $100 \%$ FDI in defence is permitted after government approvals if it brings in niche military technologies. Despite India being the 2nd largest arms importer in the world in an oligopsonic arms market and various measures by the government to attract foreign funding, FDI inflows in defence have been meagre. This paper makes an attempt to qualitatively identify the reasons for poor FDI inflows in defence, compare policies on FDI in defence in other countries, carry out a SWOT analysis on FDI in defence and discuss the requirement of FDI in defence in India. The paper also attempts to quantitatively analyse the trend of FDI inflows in defence using a bivariate regression model and forecast the future FDI inflows in defence using an autoregressive moving average (ARMA) model.
\end{abstract}

Keywords - FDI in Defence, SWOT, Bivariate regression, ARMA,

Abbreviations - Foreign direct Investment (FDI), Department for Promotion of Industry and Internal Trade (DIPP), Ministry of Defence (MoD), Original Equipment Manufacturer (OEM).

JEL Codes - C22, E22, E47, F52, M19.

\section{INTRODUCTION}

FDI is a need-based concept wherein a host nation needs FDI for accelerated growth, prospective investors are guided purely by economic considerations. Foreign companies invest in India to take advantage of relatively lower wages, special investment privileges and tax exemptions, etc. AT Kearney, a global management firm analyses the impact of likely political, economic, and regulatory changes on the FDI in various countries by measuring the 'FDI Confidence Index' and publishes a ranking of top 25 countries in the FDI confidence Index. India was in the top five countries till 2013 and has always been among the top 25 countries in FDI Confidence Index, indicating that India is a favourite destination for foreign firms to invest. Fig-1 refers. India has also been the $5^{\text {th }}$ largest defence spender, and $2^{\text {nd }}$ largest arms importer creating near oligopsonic market conditions for defence imports. It therefore makes financial sense to exploit this oligopsony through FDI inflows to the country to boost local manufacturing.

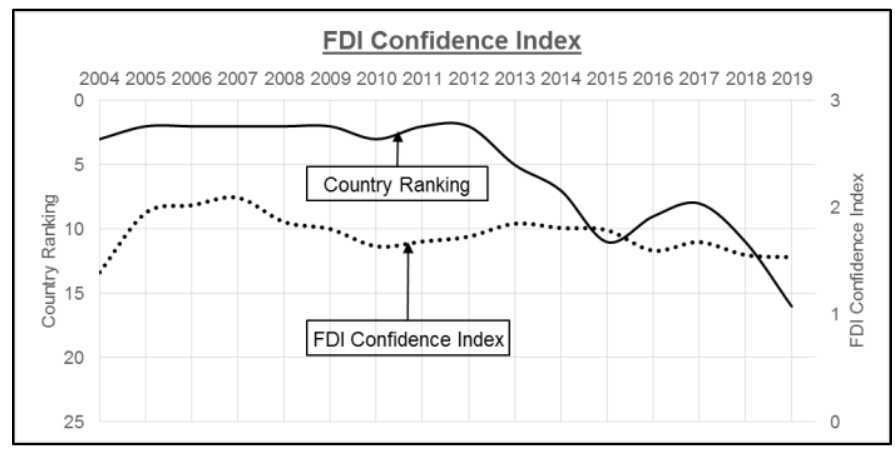

Fig-1: (FDI Confidence Index)

Source: AT Kearney FDI Confidence Index Publications

Given the sensitivity attached to defence, FDI was not permitted in defence till 2001. It has been gradually opened up with provisions of up to $100 \%$ FDI in defence after government approvals and up to 49\% FDI in defence through automatic route. Despite numerous initiatives by the government of India, the FDI inflows in defence has remained marginal and less than $0.0002 \%$ of the total FDI inflows. FDI in defence has been ranked at 62 amongst the 63 sectors of FDI inflows as depicted in Fig 2.

\section{LITERATURE REVIEW}

In a major policy change in May 2001, the government opened up India's defence production to the private sector as well as foreign participation [1]. FDI up to $26 \%$ in defence subject to compulsory industrial licensing was permitted in consonance with the Indian Companies Act, 1956. In 2002 as an amplification to FDI in defence, guidelines for licensed production of arms \& ammunitions stipulated a three year lockin period for all defence equity inflows and no purchase guarantee from the $\mathrm{MoD}$ [2]. 


\section{International Journal of Engineering Applied Sciences and Technology, 2019 \\ Vol. 4, Issue 8, ISSN No. 2455-2143, Pages 280-289 \\ Published Online December 2019 in IJEAST (http://www.ijeast.com)}

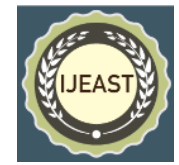

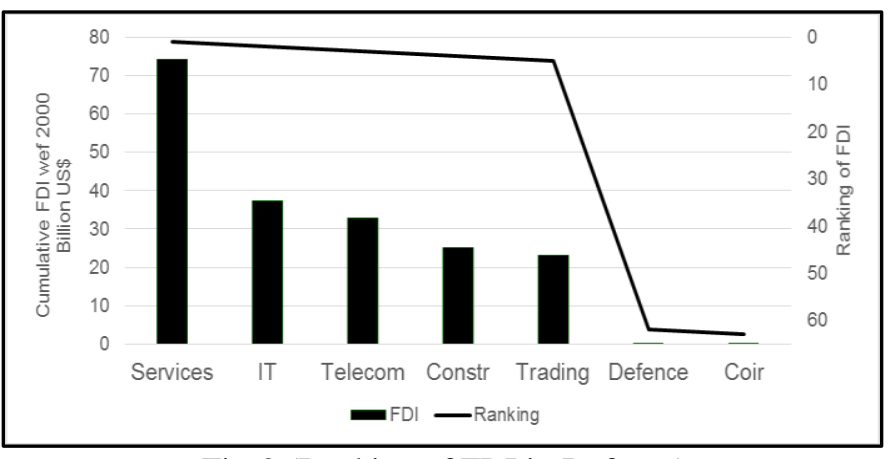

Fig-2 (Ranking of FDI in Defence) Source: DIPP, MoCI

The total FDI inflows from Apr 2000 till Dec 2009 stood at 1,10,760 million US\$ of which defence contributed a meagre 1.5 lakh US\$ which was about $0.0001 \%$ of the total FDI resulting in debates to increase the FDI limit began both at governmental and non-governmental levels. A spate of starred, un-starred and short notice questions in both the houses of the parliament were answered by the MoD clarifying that the government had no plans to increase the FDI in defence.

The FDI limit of $26 \%$ was a major hurdle to fulfil the mandatory offset obligation of $30 \%$ for defence contracts greater than 300 Crores introduced in DPP-2006. Any Joint Venture (JV) of a foreign OEM required the Indian firm of the JV to make huge investments and finding such an Indian firm ready to make heavy investments was difficult. In 2009, the defence expenditure review committee, headed by VK Misra recommended an increase of FDI cap to 49\%. Defence thinktanks such as Takshashila Institution [3], IDSA [4] and Indian Defence Review [5] also recommended increase in FDI limit from the existing $26 \%$.

In May 2010, Department for Promotion of Industry and Internal Trade (DIPP) published a discussion paper strongly recommending increasing the FDI cap in defence, stating FDI cap of $26 \%$ has failed to attract any worthwhile FDI in defence and limiting FDI to less than $50 \%$ would not benefit foreign investors in the management of the invested company [6]. In response, the Federation of Indian Chambers of Commerce \& Industry (FICCI) advised caution on increasing cap on FDI in defence and recommended selective increase of the cap to $49 \%$ FDI only if certain special conditions were met [7]. A survey by Confederation of Indian Industries (CII) in May 2010 suggested that the Indian defence industry supported enhanced FDI levels of up to 49\%, but opposed 100\% FDI in the sector [8]. A KPMG Survey with Indian and foreign defence vendors showed 57\% favoured increase of FDI cap in defence from existing $26 \%$ to $49 \%$ or more, while $17 \%$ opposed and $26 \%$ were undecided [9]. Most foreign vendors however favoured increase in FDI to more than $51 \%$ stating that without adequate economic returns and control, foreign defence/security companies would find other markets more attractive for investment and technology development. Senior defence officers in the Indian military also expressed the need to increase FDI in defence in order to speed up the development of cutting-edge weapon technologies and boost exports. US-India Business Council (USIBC) requested for FDI in defence to be increased to 74\% [10]. The Naresh Chandra Committee too in 2012 recommended increase in FDI cap in defence.

In 2013 the then Defence Minister Shri AK Antony shot down the then Commerce Minister Shri Anand Sharma's proposal to increase FDI in defence to 74\% [11]. However, rejecting the MoD's view on FDI, a Parliamentary Standing Committee in 2013 recommended increase in FDI to attract foreign investment and save precious foreign exchange. Within the MoD while the Department of Defence Production (DDP) was against increasing FDI limit, the DRDO was in favour.

Change in government in May 2014 saw three Defence Ministers- Shri AK Antony, Shri Arun Jaitley and Shri Manohar Parrikar head the MoD in succession during the year. "Make in India" became the buzzword in the corridors of MoD. A list of items requiring industrial license was notified \& clarified that items not included in the list would not require an industrial license bringing about the much needed clarity especially for dual use items having both military and civilian applications [12]. FDI in defence was increased to $49 \%$ with government approvals in Jul 2014. FDI limit of 49\% was however all inclusive i.e. Foreign Direct Investment (FDI), Foreign Institutional Investors (FII), Foreign Portfolio Investment (FPI), Non Resident Investments (NRIs), Foreign Venture Capital Investor (FVCI) and Qualified Foreign Investors (QFI). For FDI in defence beyond $49 \%$, the proposal would be routed to Cabinet Committee on Security (CCS) on a case to case basis, wherever it is likely to result in access to modern and state-of-art technology in the country.

In 2015, in an unprecedented move the government allowed FDI up to $49 \%$ in the defence under the automatic route without government approvals [13]. For FDI beyond 49\%, prior government approval continued to be required on a case to case basis, wherever it would result in access to 'state-of-art' technologies and the Indian investee company should be selfsufficient in areas of product design, development and should also have maintenance and life cycle support facility of the product being manufactured in India.

In June 2016, the government further liberalised the FDI in defence by replacing 'state of art' with 'modern' and permitting FDI for the manufacture of small arms and ammunition covered under the Arms Act 1959. The Foreign Investment Promotion Board (FIPB) was abolished and DIPP processed applications on the Foreign Investment Promotion Portal (FIFP) and forward them to the concerned ministries for approvals. The CCS approval was also no longer required. In addition requirement of a single largest Indian ownership of 51\% 


\section{International Journal of Engineering Applied Sciences and Technology, 2019 \\ Vol. 4, Issue 8, ISSN No. 2455-2143, Pages 280-289 \\ Published Online December 2019 in IJEAST (http://www.ijeast.com)}

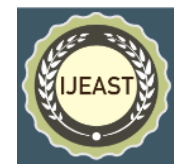

of equity was removed and a lock-in period of three years on equity transfer was also done away with.

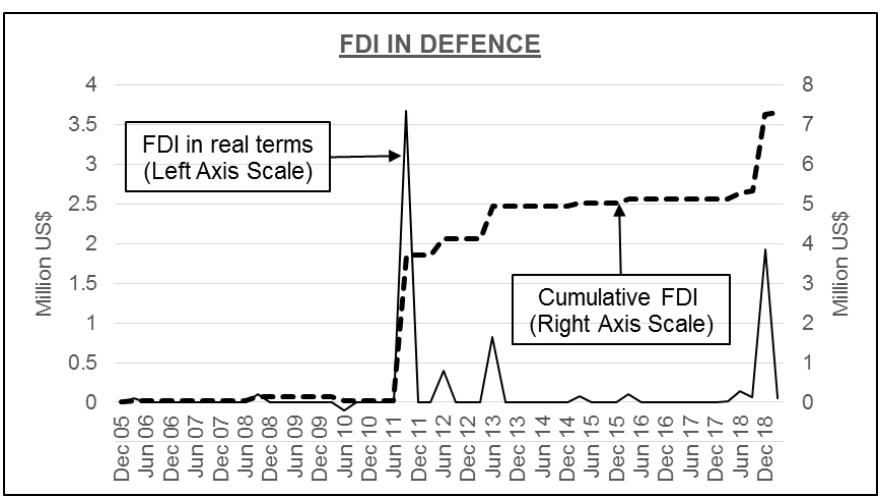

Fig-3 (FDI in Defence)

Source: DIPP, MoCI

Despite these changes, there seems to be a lackluster investor appetite for FDI in defence. The singular proposal from $\mathrm{M} / \mathrm{s}$ Naval Group, a French firm seeking 100\% FDI for investment of 15 million US\$ to develop Air Independent Propulsion (AIP) systems for the submarines was also rejected by the government, since DRDO insisted that the technology was not modern [14].

The FDI inflows in defence from Dec 2005 till Mar 2019 is shown at Fig-3. While the cumulative FDI in defence has been raising over the years, the percentage of cumulative FDI in defence of the total cumulative FDI has been on the decline, especially from 2012 onwards indicating that the FDI inflows in defence sector has not kept pace with the increasing FDI in other sectors. Fig-4 refers.

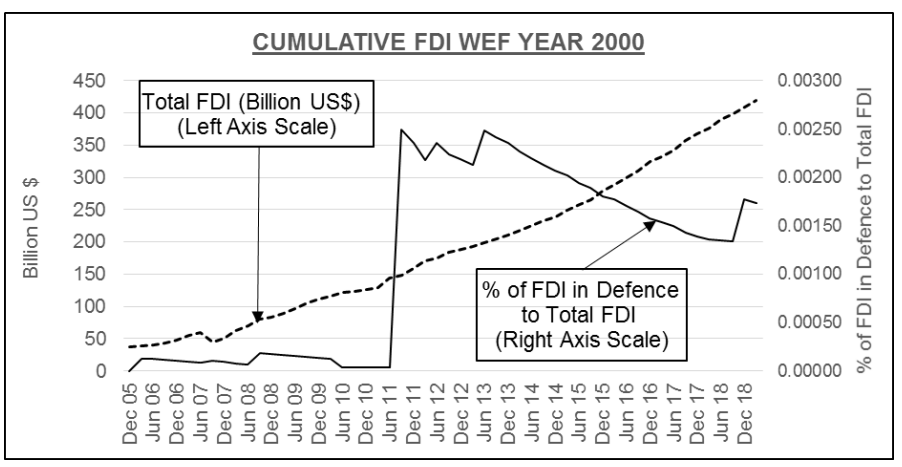

Fig-4 (FDI in Defence as a \% of Total FDI) Source: DIPP, MoCI

The three major defence employees' unions - All India Defence Employees Federation (AIDEF), Indian National Defence Workers Federation (INDWF), and Bharatiya Pratiraksha Mazdoor Sangh (BPMS) have been representing against increase of FDI in defence and privatisation of defence industry [15]. The MoD has however clarified that the proposal is to convert Ordnance Factory (OF) into a Defence Public Sector
Undertaking (DPSU) which is corporatisation of OFs and not privatisation of OFs [16].

\section{REASONS FOR MEAGRE FDI IN DEFENCE}

Question of Control. The policy of FDI cap of $49 \%$ through automatic route is not lucrative enough for foreign OEMs to invest in India. Although conditions that the company being invested should be an Indian company with its management in Indian hands have been removed, still conditions such as majority representation on the board and the chief executive of the company to be resident Indian have discouraged foreign OEMs who desire a degree of control over the invested firm.

Hesitancy to Share Military Technology. Military technologies are niche, sensitive, proprietary and more often than not, under stringent government controls and cannot be traded or shared as open market transactions. Foreign governments and OEMs maintain stringent control over these technologies in their national interests. Even though $100 \%$ FDI in defence for transfer of 'State of the Art' or 'Modern Technology' has been permitted, this facility has not been exploited due to this reason.

Guarantee for Quality. Guidelines on FDI in defence, mandates foreign OEMs to be jointly responsible for the quality of defence products manufactured along with the Indian partner. Foreign OEMs are however reluctant to accept this responsibility. The recent case of French Dassault Aviation refusing to accept responsibility for the quality of Rafale aircrafts manufactured in India by M/s HAL led to the deal collapsing.

Too Many Regulators. While the defence sector is under the MoD, the Ministry of Home Affairs (MHA) controls internal security and police. The DIPP issues licences for all defence products other than small arms which under the Arms Act 1959 is governed by MHA. Foreign OEMs are therefore regulated by the MoD, MHA and DIPP almost concurrently for requisite clearances.

Policy Uncertainty. There exists ambiguity on what exactly constitutes the "Defence" sector especially when it comes to manufacturing of minor parts and components which have dual-use. There is also a significant overlap in the list of items covered under "small arms" and "ammunition" of the Arms Act which do not require industrial licence. As an eg, M/s Boeing makes military as well as commercial aircrafts, and hence there is ambiguity on classification of investments by $\mathrm{M} / \mathrm{s}$ Boeing for manufacture of aircrafts in India.

Stringent Arms Act. The Arms Act 1959 prescribes mandatory prior approval when there is a change in the directorship, control or ownership, in its key managerial personnel or even any change in shareholding of the company beyond $5 \%$ discouraging foreign investors. 


\section{International Journal of Engineering Applied Sciences and Technology, 2019 \\ Vol. 4, Issue 8, ISSN No. 2455-2143, Pages 280-289 \\ Published Online December 2019 in IJEAST (http://www.ijeast.com)}

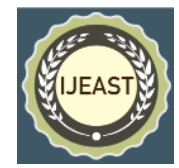

Industrial Licensing. While FDI of less than $49 \%$ in defence is permitted automatically without approvals, Industrial licensing is required for production of items under the Arms Act, in effect requiring some sort of government approval, although being under automatic route.

Unclear Policies. Policies are still unclear on the implications of a foreign OEM which has invested under the automatic route, but later undergoes a change in shareholding pattern to more than $49 \%$, or for transfer of stake by an existing investor to an existing foreign investor within the permitted automatic route level.

Security Clearance Conundrum. Security clearance of the foreign investor investing through automatic route without government approvals occurs post investment at the time of obtaining a license under the Arms Act. A negative report on security aspects could lead to the entire transaction having to be unwound discouraging foreign investors.

Underdeveloped Supporting Ecosystem. Antiquated labour laws and difficulty in acquisition of land is a well-known problem in India. The investee / joint venture company has to be self-sufficient in product design, development and manufacturing facility and provide life cycle maintenance and support to the product being manufactured in India.

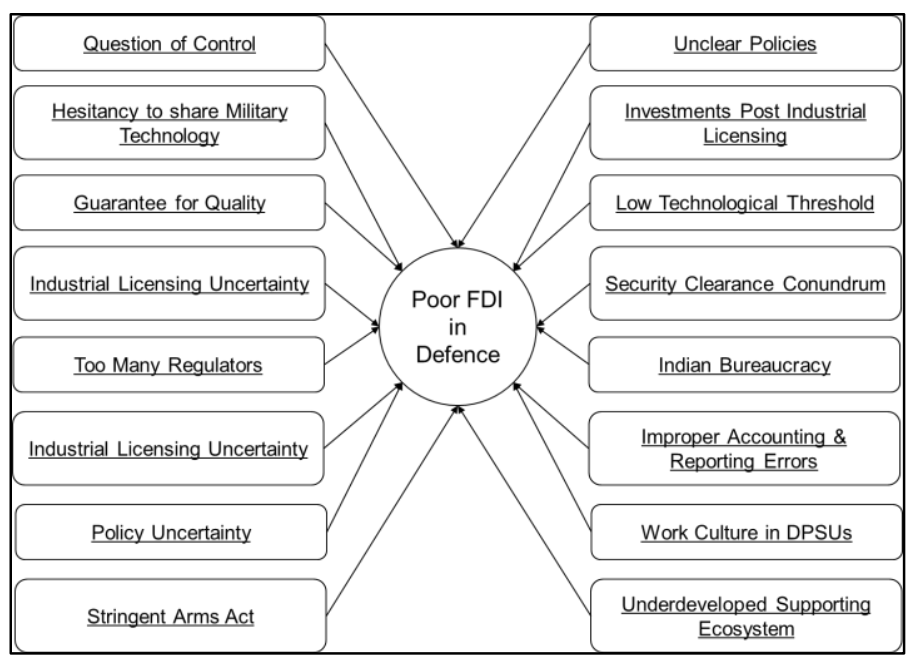

Fig 5 (Reasons for Poor FDI in Defence)

Source: Author's Representation

Lack of Choice of Indian Defence Industry Partners. None of Indian defence firms public or private figure in the top 10 global defence firms. The private defence industry is just about emerging and is limited to manufacturing parts and subassemblies with no proven capabilities. The DPSUs are government controlled and foreign firms if investing in DPSUs will have little say in the functioning of the DPSUs. Weak technological threshold and huge cost and time overruns of the Indian defence industry, particularly the DPSUs is a known fact. The cost of manufacturing an SU-30 aircraft by HAL under
Transfer of Technology (ToT) is more than the cost of buying the same aircraft from Russia. Hence, there is very little choice for the foreign OEMs investing in India in choosing a suitable Indian partner.

Domestic \& International Markets. Arms market in India is monopsonic. The Indian government as the only customer and does not give any assurance of procurements or minimum order quantity at the same time imposing strict control on exports.

Indian Bureaucracy. There is political interference, perverse incentives for career advancement, lack of specialised expertise, and a perception of widespread corruption in the Indian bureaucracy. India's ranking in the 'Ease of Doing Business' published by the World Bank is around 130 amongst 190 countries. It is only in 2019 that it has risen to a fairly respectable figure of 77 . Corruption, scams and cancellation of defence projects after multiple negotiations discourage foreign OEMs from investing in India.

Work Culture in DPSUs. Indian DPSUs and OFs suffer huge cost and time overruns even for licensed production. The DPSUs are seen more for employment generation and the resultant vote banks and less towards the achieving the elusive self-reliance in defence. The three major defence employees' unions have been representing against increase of FDI in defence and privatisation of defence industry. Attempts by the government to privatise the DPSUs and OFs have repeatedly failed.

Improper Accounting \& Reporting Errors. Most foreign OEMs in defence are system aggregators who obtain components and sub systems from different manufacturers across the globe. Setting up facilities for manufacturing parts and components or integration facilities for defence products in India, may not in the true sense, be listed against FDI in defence. In addition, Rao et al. (2018) in their work highlight delayed reporting, notional inflows, inappropriate industrial classification, round-tripping etc lead to reporting errors [17].

\section{FDI IN DEFENCE IN OTHER COUNTRIES}

Foreign defence OEMs persistently demand raising foreign investment caps in the defence sector, reasoning increased foreign investments and rapid technological up gradation of the domestic defence industrial base in most developing countries. However, most developed economies feel threatened by increasing equity investments by foreign government-owned and/ or foreign government-controlled entities in the defence. Primary concern from a national security perspective is that foreign OEMs could restrict defence supplies to host governments at a crucial juncture and use acquired technologies to harm host government's security interests. Foreign OEMs could also be used for surveillance, infiltration and sabotage against the host governments and may also result 
in widespread infusion of low-end technologies which could wipe out the nascent defence industrial bases of the host countries.

About 90 per cent of Europe's defence industrial base is located in six countries viz; UK, France, Germany, Italy, Spain and Sweden. Most of the countries in EU have restrictions on FDI in defence. O'Donnell et al. (2010) has highlighted that UK does not allow any foreign shareholder to own more than $15 \%$ in BAE and Rolls Royce in addition to stipulations of only UK nationals in the board of management of these companies [18]. Verma et al. (2013) has highlighted that France opposes any investor acquiring more than $10 \%$ of shares in its defence industries. Governments of Germany and UK review all FDI in defence. Government approvals for FDI of over 3\% in defence is mandatory in Italy. Countries like Austria, Denmark, Poland, Spain and Sweden require government approvals for any FDI in defence. Finland, Lithuania and Slovenia out-rightly prohibit all non-EU and non-NATO FDI in defence [19]. Fiott et al. (2012) has noted that US stipulates all board members to be US nationals only in all its defence firms, it also exercises its authority to supervise, prohibit and/ or make changes to foreign holdings in any industry in the US, in case FDI in that industry is assessed to be a potential threat to its national security [20].

Defence is in the negative list for foreign entrepreneurs and there are restrictions on maximum foreign ownership in the Presidential Decree in Indonesia [21]. Government approval is necessary for investments in defence in Russia [22]. Brazil has limitations of foreign investments in defence. UAE restricts all foreign investment to $49 \%$. Investments in sensitive industries, including dual is required to be notified to the government in Japan. Closer home, terrorism, corruption, security and political instability have been major obstacles in FDI inflows and economic growth in Pakistan. Bangladesh does not permit FDI in defence [23].

\section{V. $\quad$ FDI IN DEFENCE: SWOT ANALYSIS}

A Strengths, Weakness, Opportunities and Threats (SWOT) analysis of FDI in defence has been carried at table 1 out to formulate strategies for the government of India to exploit external 'Opportunities', mitigate external 'Threats' by taking advantage of internal 'Strengths' and reducing internal 'Weakness'.

\begin{tabular}{|c|c|}
\hline Strengths & Weakness \\
\hline $\begin{array}{l}\text { - } \text { Boost GDP \& local manufacturing. } \\
\text { - } \text { Geduce import bills. } \\
\text { - } \text { Easier discharge of offsets. } \\
\text { - } \text { Cheaper spares and better maintenance. } \\
\text { - } \text { Faster modernisation of Indian Armed Forces. } \\
\text { - Local manufacturing would be cheaper than import. } \\
\text { - } \text { DRDO/DPSUs can collaborate with foreign OEMs and } \\
\text { improve technological threshold. } \\
\text { - Higher FDI limits in other sectors have not stymied the growth } \\
\text { of Indigenous industry Higher FDI limits in other sectors have } \\
\text { not stymied the growth of Indigenous industry. } \\
\text { - Increased availability of equipment and spares even during } \\
\text { crisis / war as compared to direct imports. } \\
\text { Greater control by government on locally manufactured } \\
\text { equipment. }\end{array}$ & $\begin{array}{l}\text { - Not in national interest to increase. } \\
\text { - Compromise of national security. } \\
\text { - Most countries do not encourage. } \\
\text { - Indigenous R\&D would suffer. } \\
\text { - India's FDI cap of } 49 \% \text { is one of the highest in the world. } \\
\text { - Local manufacturing may turn out to be costlier than import. } \\
\text { - Mediocrity and lack of accountability of DRDO/DPSU/OFs. } \\
\text { - DRDO / DPSUs/OFs have huge cost and time overruns. } \\
\text { - Long time required for modernisation with Indigenous } \\
\text { - } \text { FDI is not permitted in many other sectors also in India. } \\
\text { - Poor technological threshold of Indian defence industry to } \\
\text { - } \text { Provorb technology. } \\
\text { - } \text { Pochnologion already exists for } 100 \% \text { FDI if it brings in niche } \\
\text { - } \text { absorb technology reduce Indian partners to mere spectators. }\end{array}$ \\
\hline Opportunities & Threats \\
\hline $\begin{array}{l}\text { - Availability of niche military technologies. } \\
\text { - Bring in necessary capital. Bring in necessary capital. } \\
\text { - Global companies cannot ignore Indian markets irrespective } \\
\text { of FDI limits. } \\
\text { - Niche military technologies closely guarded by governments } \\
\text { and control regimes. }\end{array}$ & $\begin{array}{l}\text { - India's internal security may get affected India's internal } \\
\text { - } \text { Decurity may get affected } \\
\text { - } \text { Foreign OEMs may limit production during crisis / war. } \\
\text { - Exclusive dependence to a country. } \\
\text { - Threaten with job retrenchments if adequate orders not } \\
\text { - } \text { provided. } \\
\text { - Critical technology may be shared with other countries by the } \\
\text { foreign OEM. }\end{array}$ \\
\hline
\end{tabular}


International Journal of Engineering Applied Sciences and Technology, 2019

Vol. 4, Issue 8, ISSN No. 2455-2143, Pages 280-289

Published Online December 2019 in IJEAST (http://www.ijeast.com)

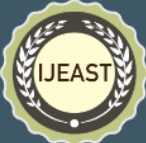

\begin{tabular}{|l|l|}
\hline & $\begin{array}{l}\text { Equipment may be exported to inimical countries. Equipment } \\
\text { may be exported to inimical countries. }\end{array}$ \\
\hline
\end{tabular}

Table 1 (SWOT Analysis FDI in Defence)

\section{ESTIMATION OF FUTURE FDI IN DEFENCE INFLOWS IN INDIA}

Secondary data of FDI inflows quarterly from Dec 2005 till Sep 2019 has been obtained from government website [24] at table 2. In real terms FDI inflows in defence has been minimal and irregular, it has however shown sharp peaks in Sep 2011, Jun 2012, Jun 2013 and Dec 2018. The summary statistics of the FDI in Defence is at table 3. The average FDI inflows in Defence in a quarter is 0.136 Million US\$ with a Standard Deviation of 0.56 Million US\$.

\begin{tabular}{|c|c|c|c|c|c|c|c|}
\hline \multicolumn{8}{|c|}{ FDI in Defence in Million US\$ } \\
\hline $\begin{array}{l}\text { Dat } \\
\mathrm{e}\end{array}$ & $\begin{array}{l}\text { Amou } \\
\text { nt }\end{array}$ & $\begin{array}{l}\text { Dat } \\
\mathrm{e}\end{array}$ & $\begin{array}{l}\text { Amou } \\
\text { nt }\end{array}$ & $\begin{array}{l}\text { Dat } \\
\mathrm{e}\end{array}$ & $\begin{array}{l}\text { Amou } \\
\text { nt }\end{array}$ & $\begin{array}{l}\text { Dat } \\
\mathrm{e}\end{array}$ & $\begin{array}{l}\text { Amou } \\
\text { nt }\end{array}$ \\
\hline $\begin{array}{l}\text { De } \\
\text { c } \\
05\end{array}$ & 0.00 & $\begin{array}{l}\text { Jun } \\
09\end{array}$ & 0.00 & $\begin{array}{l}\text { Dec } \\
12\end{array}$ & 0.00 & $\begin{array}{l}\text { Jun } \\
16\end{array}$ & 0.00 \\
\hline $\begin{array}{l}\mathrm{Ma} \\
\text { r } 06\end{array}$ & 0.05 & $\begin{array}{l}\text { Sep } \\
09\end{array}$ & 0.00 & $\begin{array}{l}\text { Mar } \\
13\end{array}$ & 0.00 & $\begin{array}{l}\text { Sep } \\
16\end{array}$ & 0.00 \\
\hline $\begin{array}{l}\text { Jun } \\
06\end{array}$ & 0.00 & $\begin{array}{l}\text { Dec } \\
09\end{array}$ & 0.00 & $\begin{array}{l}\text { Jun } \\
13\end{array}$ & 0.82 & $\begin{array}{l}\text { Dec } \\
16\end{array}$ & 0.00 \\
\hline $\begin{array}{l}\text { Sep } \\
06\end{array}$ & 0.00 & $\begin{array}{l}\text { Mar } \\
10\end{array}$ & 0.00 & $\begin{array}{l}\text { Sep } \\
13\end{array}$ & 0.00 & $\begin{array}{l}\mathrm{Ma} \\
\mathrm{r} 17\end{array}$ & 0.00 \\
\hline $\begin{array}{l}\text { De } \\
\text { c } \\
06\end{array}$ & 0.00 & $\begin{array}{l}\text { Jun } \\
10\end{array}$ & 0.00 & $\begin{array}{l}\text { Dec } \\
13\end{array}$ & 0.00 & $\begin{array}{l}\text { Jun } \\
17\end{array}$ & 0.00 \\
\hline $\begin{array}{l}\mathrm{Ma} \\
\text { r } 07\end{array}$ & 0.00 & $\begin{array}{l}\text { Sep } \\
10\end{array}$ & 0.00 & $\begin{array}{l}\text { Mar } \\
14\end{array}$ & 0.00 & $\begin{array}{l}\text { Sep } \\
17\end{array}$ & 0.00 \\
\hline $\begin{array}{l}\text { Jun } \\
07\end{array}$ & 0.00 & $\begin{array}{l}\text { Dec } \\
10\end{array}$ & 0.00 & $\begin{array}{l}\text { Jun } \\
14\end{array}$ & 0.00 & $\begin{array}{l}\text { Dec } \\
17\end{array}$ & 0.00 \\
\hline $\begin{array}{l}\text { Sep } \\
07\end{array}$ & 0.00 & $\begin{array}{l}\text { Mar } \\
11\end{array}$ & 0.00 & $\begin{array}{l}\text { Sep } \\
14\end{array}$ & 0.00 & $\begin{array}{l}\mathrm{Ma} \\
\mathrm{r} 18\end{array}$ & 0.01 \\
\hline $\begin{array}{l}\text { De } \\
\text { c } \\
07\end{array}$ & 0.00 & $\begin{array}{l}\text { Jun } \\
11\end{array}$ & 0.00 & $\begin{array}{l}\text { Dec } \\
14\end{array}$ & 0.00 & $\begin{array}{l}\text { Jun } \\
18\end{array}$ & 0.14 \\
\hline $\begin{array}{l}\mathrm{Ma} \\
\text { r } 08\end{array}$ & 0.00 & $\begin{array}{l}\text { Sep } \\
11 \\
\end{array}$ & 3.57 & $\begin{array}{l}\text { Mar } \\
15\end{array}$ & 0.08 & $\begin{array}{l}\text { Sep } \\
18\end{array}$ & 0.07 \\
\hline $\begin{array}{l}\text { Jun } \\
08\end{array}$ & 0.00 & $\begin{array}{l}\text { Dec } \\
11\end{array}$ & 0.00 & $\begin{array}{l}\text { Jun } \\
15\end{array}$ & 0.00 & $\begin{array}{l}\text { Dec } \\
18\end{array}$ & 1.92 \\
\hline $\begin{array}{l}\text { Sep } \\
08\end{array}$ & 0.10 & $\begin{array}{l}\text { Mar } \\
12 \\
\end{array}$ & 0.00 & $\begin{array}{l}\text { Sep } \\
15 \\
\end{array}$ & 0.00 & $\begin{array}{l}\mathrm{Ma} \\
\text { r } 19\end{array}$ & 0.05 \\
\hline $\begin{array}{l}\text { De } \\
\text { c } \\
08\end{array}$ & 0.00 & $\begin{array}{l}\text { Jun } \\
12\end{array}$ & 0.40 & $\begin{array}{l}\text { Dec } \\
15\end{array}$ & 0.00 & $\begin{array}{l}\text { Sep } \\
19\end{array}$ & 0.01 \\
\hline $\begin{array}{l}\mathrm{Ma} \\
\text { r } 09\end{array}$ & 0.00 & $\begin{array}{l}\text { Sep } \\
12\end{array}$ & 0.00 & $\begin{array}{l}\text { Mar } \\
16\end{array}$ & 0.10 & & \\
\hline
\end{tabular}

Table 2 (FDI in Defence in ndia)

Source : DIPP, MOCI
The maximum FDI inflow in Defence in a quarter is 3.57 Million US\$. The high levels of Skewness (5.32) and Kurtosis (30.11) indicate that the distribution is not Normal, hence no other tests for normality were conducted.

\begin{tabular}{|l|l|l|l|l|r|}
\hline \multicolumn{6}{|c|}{ Quarterly FDI in Defence (Dec 2005 to Sep 2019) Million US\$ } \\
\hline Ser & Statistics & Value & Ser & Statistics & Value \\
\hline (a) & Mean & 0.135555556 & (h) & Skewness & 5.31973885 \\
\hline (b) & $\begin{array}{l}\text { Standard } \\
\text { Error }\end{array}$ & 0.075531042 & (i) & Range & 3.57 \\
\hline (c) & Median & 0 & (j) & Maximum & 3.57 \\
\hline (d) & Mode & 0 & (k) & Minimum & 0.00 \\
\hline (e) & $\begin{array}{l}\text { Standard } \\
\text { Deviation }\end{array}$ & 0.555037536 & (l) & Sum & 7.32 \\
\hline (f) & $\begin{array}{l}\text { Sample } \\
\text { Variance }\end{array}$ & 0.308066667 & (m) & Count & 54 \\
\hline (g) & Kurtosis & 30.1103875 & (n) & $\begin{array}{l}\text { Avg Absolute } \\
\text { Deviation }\end{array}$ & 0.2286008 \\
\hline
\end{tabular}

Table 3 (Summary Statistics FDI in Defence)

$\underline{\text { Trend Analysis }}$

In order to examine the trend of FDI in Defence inflows a Trend Analysis was attempted with the help of Bivariate Regression Model as under-

FDI in Defence $(\mathrm{t})=\alpha+\beta *($ Time in Years $)+\varepsilon(\mathrm{t})$

Where FDI in defence inflows in Million US\$ is the dependent variable and time in years is the independent variable. The regression coefficients ' $\alpha \& \beta$ ' are the intercept ' $\alpha$ ' indicating the hypothetical value of FDI inflows in defence without trend and the slope coefficient ' $\beta$ ' representing the annual trend of FDI inflows in defence. The results of the Regression analysis are at table 4.

\begin{tabular}{|c|c|c|c|c|c|c|}
\hline \multicolumn{7}{|c|}{ Regression Statistics } \\
\hline \multicolumn{4}{|l|}{ Multiple R } & \multicolumn{3}{|c|}{0.082348013} \\
\hline \multicolumn{4}{|l|}{ R Square } & \multicolumn{3}{|c|}{0.006781195} \\
\hline \multicolumn{3}{|c|}{ Adjusted R Square } & \multicolumn{4}{|c|}{-0.012319166} \\
\hline \multicolumn{3}{|c|}{ Standard Error } & \multicolumn{4}{|c|}{0.558445871} \\
\hline \multicolumn{3}{|c|}{ Observations } & \multicolumn{4}{|c|}{54} \\
\hline \multicolumn{7}{|l|}{ ANOVA } \\
\hline & $d f$ & & & $M S$ & $F$ & Significance $F$ \\
\hline Regression & 1 & & 0191 & 0.110720191 & 0.355029676 & 0.553864458 \\
\hline Residual & 52 & & 1314 & 0.311861791 & & \\
\hline \multirow[t]{2}{*}{ Total } & 53 & & 3333 & & & \\
\hline & & & ents & $\begin{array}{c}\text { Standard } \\
\text { Error }\end{array}$ & $t$ Stat & $P$-value \\
\hline \multicolumn{2}{|c|}{ Intercept } & \multicolumn{2}{|c|}{0.055660377} & 0.154125506 & 0.361136704 & 0.719460393 \\
\hline \multicolumn{2}{|c|}{ Time (Quarterly) } & \multicolumn{2}{|c|}{0.011621117} & 0.019503634 & 0.595843667 & 0.553864458 \\
\hline
\end{tabular}

Table 4 (Regression Analysis FDI in Defence)

Since the 'P Value' of the independent variable (Time) is 0.55 which is $>>0.05$, there is a good chance that the correlation of the two variables is due to randomness and not necessarily due to any relationship. In addition the low value of 


\section{International Journal of Engineering Applied Sciences and Technology, 2019 \\ Vol. 4, Issue 8, ISSN No. 2455-2143, Pages 280-289 \\ Published Online December 2019 in IJEAST (http://www.ijeast.com)}

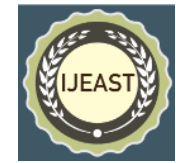

'Multiple R' $(0.08)$ does not positively indicate any correlation between 'Time' and 'FDI in Defence'. Hence the trend of the 'FDI in Defence' cannot be positively established using this model. This can also be observed in the data wherein, there is Zero (0) FDI in defence for a few quarters and spikes in FDI in defence in some other quarters.

\section{ARMA Model for Analysing \& Forecasting FDI in Defence}

Autoregressive Moving Average (ARMA) [25] provides a parsimonious description of a weakly stochastic process in terms of two polynomials, one for the Autoregression (AR) and the other for Moving Average (MA). Given a time series of data $x_{t}$, the ARMA model is a tool for understanding and predicting future values in this series. The AR part involves regressing the variable on its own past values and the MA part involves modelling the error term as a linear combination of error terms occurring contemporaneously and at various times in the past. The model is usually referred to as the $\operatorname{ARMA}(\mathrm{p}, \mathrm{q})$ model where $p$ is the order of the AR part and $q$ is the order of the MA part. ARMA models can be estimated by using the Box-Jenkins method which starts with the assumption that the process that generated the time series can be approximated using an ARMA model if it is 'Stationary'. Stationarity of data signifies that the mean, variance and autocorrelation structure do not change over time. 'Augmented Dickey Fuller' (ADF) Test which tests the data for a unit root is one of the most preferred tests for stationarity.

\begin{tabular}{|c|c|c|c|c|c|}
\hline \multicolumn{6}{|c|}{ ADF Test for Stationarity of Data: FDI in Defence } \\
\hline $\begin{array}{l}\text { Ser } \\
\text { No }\end{array}$ & Statistics & Value & $\begin{array}{l}\text { Ser } \\
\text { No }\end{array}$ & Statistics & Value \\
\hline (a) & Criteria & Schwert & (h) & Stationary & Yes \\
\hline (b) & Drift & No & (i) & AIC & 1.7375850 \\
\hline (c) & Trend & No & (j) & BIC & 1.77441804 \\
\hline (d) & Lag & 10 & $(\mathrm{k})$ & Lags & 0 \\
\hline (e) & Alpha & 0.05 & (1) & Coeff & -0.986021 \\
\hline (f) & Tau-stat & -7.1790269 & (m) & P-value & $<0.01$ \\
\hline$(\mathrm{g})$ & Tau-crit & -1.9468083 & $(\mathrm{n})$ & & \\
\hline
\end{tabular}

The time series data of FDI in defence was tested for 'Stationarity' by ADF Test in 'Real Statistics' Excel Add-In [26]. The results of the ADF test are at table 5. The null hypothesis of the ADF test, that the data being tested is 'Non Stationary' is rejected due to the 'Tau-Statistic' $(-7.18)$ being lesser than 'Tau Critical' (-1.95) and the 'P-Value' $(0.01)$ being less than 'Alpha' (0.05). This inference is also in consonance with the results of the bivariate regression model discussed above negating any correlation between FDI in defence and time.

Having established the 'Stationarity' of the time series data of FDI in Defence, various ARMA(p,q) models were tried out for the best fit. The ARMA process $\operatorname{ARMA}(p, q)$ can be mathematically modelled as

$$
\begin{gathered}
y_{i}=\phi_{0}+\phi_{1} y_{i-1}+\phi_{2} y_{i-2}+\cdots+\phi_{p} y_{i-p}+\varepsilon_{i}+\theta_{1} \varepsilon_{i-1}+\cdots+\theta_{q} \varepsilon_{i-q} \\
y_{i}=\phi_{0}+\sum_{j=1}^{p} \phi_{j} y_{i-j}+\varepsilon_{i}+\sum_{j=1}^{q} \theta_{j} \varepsilon_{i-j}
\end{gathered}
$$

The values of coeff $\phi$ and $\theta$ were determined by minimising the Sum of Squared Errors (SSE) of the residuals in the ARMA model using Excel Solver Add-In [27].

When a statistical model is used to represent the process that generated data, the representation will never be exact and some information will be lost by using the model to represent the process. 'Akaike Information Criterion' (AIC) measures the amount of information lost by a given model and estimates the relative quality of the statistical model. In estimating the amount of information lost by a model, AIC provides a trade-off between the 'goodness of fit' of the model and the 'simplicity' of the model thereby dealing with both the risk of 'over fitting' and 'under fitting'. The 'Bayesian Information Criterion' (BIC) also called 'Schwarz Information Criterion' penalizes models with more parameters, favouring simpler models with least number of parameters. Models with lower values of AIC and BIC are considered to be better than those with higher values. Between AIC and BIC, BIC penalises model complexity more heavily. A

\begin{tabular}{|c|c|c|c|c|c|}
\hline \multicolumn{6}{|c|}{ Comparison of ARMA $(p, q)$, FDI in Defence } \\
\hline & & \multicolumn{4}{|c|}{$\mathrm{AR}(\mathrm{p})$} \\
\hline & & 0 & 1 & 2 & 3 \\
\hline \multirow{8}{*}{ 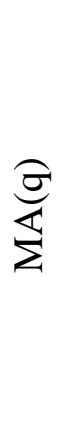 } & \multirow{2}{*}{0} & AIC & -60.705 & -56.653 & -52.658 \\
\hline & & $B I C$ & -56.727 & -50.742 & -44.853 \\
\hline & \multirow{2}{*}{1} & -60.862 & -82.396 & -52.906 & -48.658 \\
\hline & & -54.840 & -74.440 & -43.055 & -36.951 \\
\hline & \multirow{2}{*}{2} & -58.953 & -79.138 & $-\mathbf{8 5 . 8 1 2}$ & -73.255 \\
\hline & & -50.924 & -69.193 & -73.990 & -59.596 \\
\hline & \multirow{2}{*}{3} & -57.056 & -76.757 & -85.259 & -68.821 \\
\hline & & -47.019 & -64.823 & -71.467 & -53.211 \\
\hline
\end{tabular}
comparison of the various $\operatorname{ARMA}(p, q)$ models for the time series data of FDI in defence is at table 6.

Table 6. (Comparison of ARMA(p,q), FDI in Defence)

$\operatorname{ARMA}(1,1), \operatorname{ARMA}(2,2) \& \operatorname{ARMA}(2,3)$ models were observed to have significantly lower AIC \& BIC values as compared to the rest of the models. Amongst them $\operatorname{ARMA}(2,2)$ was chosen as the best fit for the time series data of FDI in Defence and parameters obtained The details of the $\operatorname{ARMA}(2,2)$ model is at table 7. Graphs of the actual FDI in Defence is at Fig 6 and the $\operatorname{ARMA}(2,2)$ model of FDI in defence till Sep 2019 is at Fig 7. 


\begin{tabular}{|l|r|l|r|l|r|}
\hline \multicolumn{5}{|c|}{ ARMA(2,2) Model for Time Series of FDI in Defence } \\
\hline$\phi_{0}$ & -0.001075 & Mean & 0.048395 & SSE & 8.37106 \\
\hline$\phi_{1}$ & 0.174937 & $\theta_{1}$ & 0.071557 & AIC & -85.8121 \\
\hline$\phi_{2}$ & 0.840265 & $\theta_{2}$ & -1.47618 & BIC & -73.9903 \\
\hline
\end{tabular}

Table 7. (ARMA(2,2) Model for FDI in Defence)

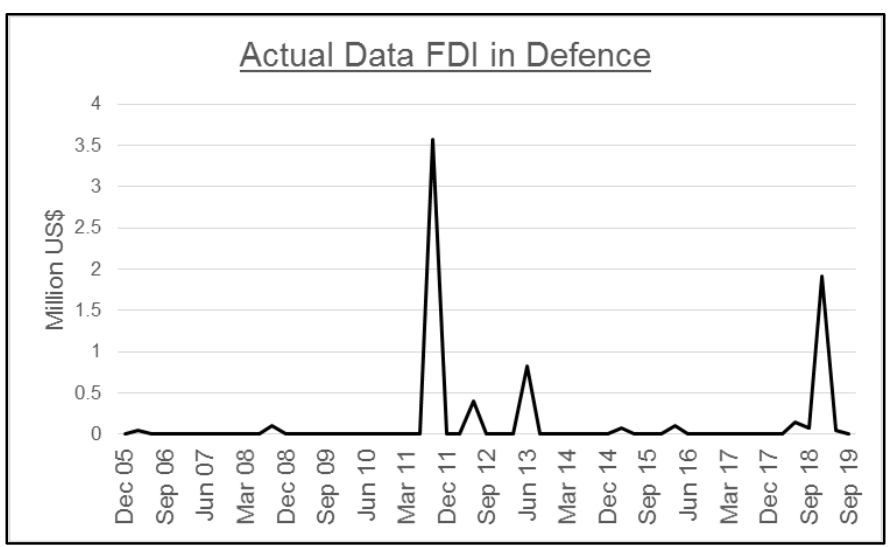

Fig 6. (Plot of Actual Data FDI in Defence)

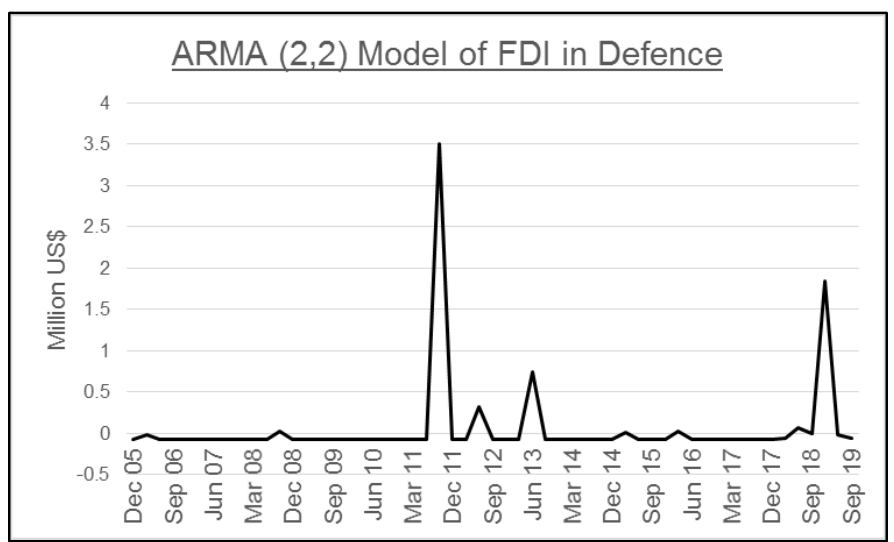

Fig 7. (Plot of ARMA(2,2) Model FDI in Defence)

Having chosen $\operatorname{ARMA}(2,2)$ as the most suitable $\operatorname{ARMA}(p, q)$ model for the time series data of FDI in defence, the model has been used to forecast the next 20 values till Sep 2024. The results of the forecast is at table 8 .

\begin{tabular}{|c|c|c|c|c|c|}
\hline \multicolumn{7}{|c|}{ Forecast of FDI in Defence in Million US\$ } \\
\hline Date & Amount & Date & Amount & Date & Amount \\
\hline Dec-19 & 0.21551 & Sep-21 & 0.27257 & Jun-23 & 0.27106 \\
\hline Mar-20 & 0.28336 & Dec-21 & 0.25564 & Sep-23 & 0.27791 \\
\hline Jun-20 & 0.22958 & Mar-22 & 0.27268 & Dec-23 & 0.27530 \\
\hline Sep-20 & 0.27719 & Jun-22 & 0.26143 & Mar-24 & 0.28060 \\
\hline Dec-20 & 0.24033 & Sep-22 & 0.27378 & Jun-24 & 0.27934 \\
\hline Mar-21 & 0.27388 & Dec-22 & 0.26649 & Sep-24 & 0.28357 \\
\hline Jun-21 & 0.24877 & Mar-23 & 0.27559 & & \\
\hline \multicolumn{7}{|c|}{}
\end{tabular}

Table 8. (Forecast of FDI in Defence)

The forecasted FDI in Defence till Sep 2024 utilising the ARMA $(2,2)$ model is at Fig- 8 . The forecasted values of FDI in defence using the $\operatorname{ARMA}(2,2)$ model is meagre, averaging to just about 0.266 million US\$ per quarter. This amount of forecasted FDI in Defence is still a minuscule of the total FDI which India attracts.

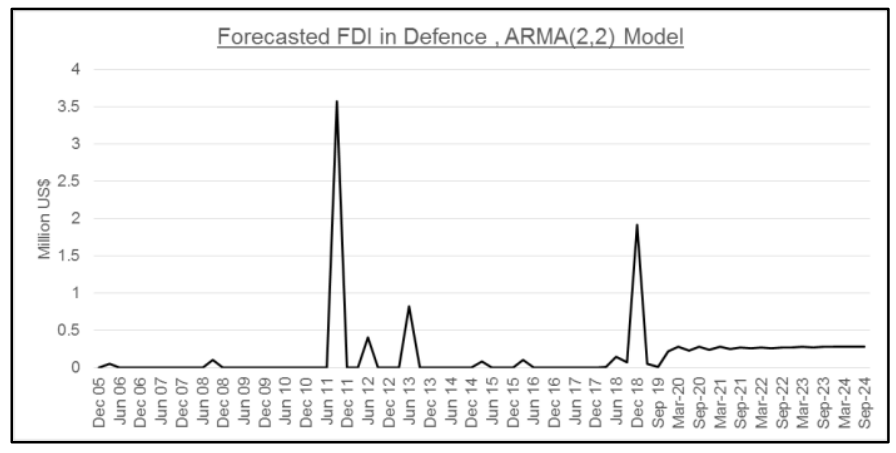

Fig 8. (Forecast of FDI in Defence Dec 2019 to Sep 2024)

\section{DO WE NEED FDI IN DEFENCE}

India is the second largest arms importer creating near oligosponic market conditions for defence imports. It therefore makes financial sense to exploit this oligospony through FDI, Offsets, JVs, etc. Availability of non-debt financial resource, generating employment and a means of obtaining foreign technology to push the 'Make in India' initiative in the defence production are some of the primary reasons for encouraging FDI in defence. India has been a favourite destination for foreign investors due to which, FDI inflows have been on a rising curve which takes care of non-debt financial resource and generating employment. At a larger perspective considering the total investments coming into India, it does not really matter as to which sector contributes to the overall FDI till the time the overall FDI inflows to India are at a comfortable level.

It is only the third requirement of attaining selfsufficiency in defence by obtaining niche and high end defence technology that the FDI in defence could fulfil. However, niche defence technology is closely guarded, controlled by governments and subject to stringent technology transfer regimes. It would be wrong to assume foreign OEMs would provide niche and state of the art technology to India easily. Notwithstanding, if a foreign OEM is genuinely interested in transfer of niche and state of the art technology, provisions of $100 \%$ FDI in defence exist.

\section{CONCLUSION}

It makes perfect sense for India to allow 100\% FDI in defence, if it brings with it niche and state of art defence technologies. This provision already exists, yet there seem to be no takers. Internationally too, considering the sensitivities of national security, countries world over have a guarded approach to FDI in defence. Even the established arms-manufacturing countries themselves practice most of these restrictions. 


\section{International Journal of Engineering Applied Sciences and Technology, 2019 \\ Vol. 4, Issue 8, ISSN No. 2455-2143, Pages 280-289 \\ Published Online December 2019 in IJEAST (http://www.ijeast.com)}

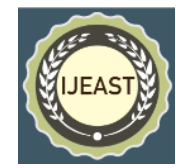

FDI in defence policy should only be an enabling measure and its success should not be measured in terms of the quantum of FDI inflows. Though the opening of the defence sector to foreign investment was crucial to lowering the barriers, it would be a folly to expect FDI in defence to behave in the same manner as it does in case of other manufacturing sectors. The expectation that higher FDI would cure all ills besetting the Indian defence industry, might be misplaced. FDI is only one of the means to get foreign technology. Most countries restrict or control foreign investments in defence. No country in the world has become self-sufficient in defence through FDI. The indigenous defence industry needs to gear up to develop high end and niche military technologies in-house. The production of military equipment within the country will provide immediate impetus to the manufacturing sector as has happened in the case of major industrialized nations like USA, France and Germany.

\section{ACKNOWLEDGMENTS}

I acknowledge my research guide, all authorities of Department of Business Management, Osmania University, Hyderabad and College of Defence Management, Secunderabad for all the support and assistance provided to me to complete this work. I am thankful to my colleagues and family for their help, constructive criticism, comments and suggestions.

\section{REFERENCES}

[1] "Revision of existing sectoral guidelines and equity cap on Foreign Direct Investment (FDI)". DIPP press note No 4 (2001) No. 5(6)/2000-FC I dated 21 May 01.

(https://dipp.gov.in/sites/default/files/press4_01.pdf).

[2] "Guidelines for licensing production of Arms \& Ammunitions DIPP press note No 2 (2002) No. 5(37)/2001-FC I dated 4 Jan 02.

(https://dipp.gov.in/sites/default/files/pn52.pdf).

[3] Singh Sushant K. (2010). FDI in India's Defence Sector - Go Beyond 51\%, Takshashila Discussion Document. (pp.1-8).

[4] Behera Laxman Kumar. (2010). A case for Increasing FDI CAP up to 100 per cent in India's Defence Industry, Fellows Seminar IDSA.

[5] Suman Maj Gen Mrinal. (2013). FDI in Defence: Dispelling the Myths. India Defence Review, 02 Sep 13, Issue Vol. 28.3.

[6] "FDI in Defence". Discussion paper DIPP. (2010) (https://dipp.gov.in/sites/default/files/DiscussionPapers_17May 2010\%20\%204.pdf)

[7] "FICCI: A Response to Discussion Paper by DIPP". (2010). (http://ficci.in/PressRelease/633/july27release.pdf).
[8] "Indian, Foreign Industries Divided over Raising FDI cap: CII". (2010).

(https://economictimes.indiatimes.com/news/economy/finance/i ndian-foreign-industries-divided-over-raising-fdi-capcii/articleshow/5909040.cms).

[9] "Opportunities in Indian Defence Sector: An Overview" (https://www.in.kpmg.com/SecureData/aci/Files/Opportunitiesi ntheIndianDefenceSector.pdf).

[10] "Union Budget 2012: Corporate America urges-Finance minister Pranab Mukherjee to issue a Bold Budget”. (2012). (https://economictimes.indiatimes.com/news/economy/policy/u nion-budget-2012-corporate-america-urges-finance-ministerpranab-mukherjee-to-issue-a-boldbudget/articleshow/12258906.cms).

[11] “AK Antony opposes proposal for hiking FDI in defence to 49\%”.(2013).

(https://economictimes.indiatimes.com/news/politics-andnation/a-k-antony-opposes-proposal-for-hiking-fdi-in-defenceto-49/articleshow/20896133.cms).

[12] "List of Defence Items requiring Industrial License". DIPP press note No 3 (2014) No. 7(3)2009-IP.Vol-III dated 26 Jun 14. (https://dipp.gov.in/sites/default/files/pn3_2014.pdf).

[13] "Review of FDI policy on various sectors". DIPP press note No 12 (2015) No. 5/8/2015-FC-1 dated 24 Nov 15. (https://dipp.gov.in/sites/default/files/pn12_2015\%20\%281\%29 .pdf).

[14] Basu Nayanima. (2016). DCNS proposal for 100\% FDI in defence project rejected, The Hindu Business Line.

(https://www.thehindubusinessline.com/economy/policy/densproposal-for-100-fdi-in-defence-project-

rejected/article9072577.ece).

[15] "FDI in Defence Production" PIB. (2017) Release ID 169209 dated Jul 17.

[16] "MoD clarifies there is no proposal to privatise OFB" PIB (2019) Release ID 192684 dated 16 Aug 19.

[17] Rao Chalapthi KS \& Biswajit Dhar. (2018) An Assessment of India's recent FDI Inflows. Institute for Studies in Industrial Development. (pp 50-65).

[18] O’Donnell Clara Marina (2010). How should Europe respond to sovereign investors in its defence sector. Policy Brief. Centre for European Reform.

(https://www.cer.eu/publications/archive/policy-

brief/2010/how-should-europe-respond-sovereign-investors-itsdefence-sec) 
[19] Verma Sandeep. (2013) FDI in Defence: Lessons for Developing Countries, IDSA Comments.

[20] Fiott, Daniel. Safeguarding the EDTIB: The Case for Supervising Non-Eu FDI in the Defence Sector (2012). Egmont Security Policy Brief, No. 41.

(https://ssrn.com/abstract=2195400)

[21] Rodl \& Partner, Investment Guide Indonesia, 2019-20. (pp$08)$.

[22] Russia Foreign Investment.

(https://santandertrade.com/en/portal/establishoverseas/russia/foreign-investment).

[23] Destination Bangladesh. (https://www.pwc.com/bd/en/assets/pdfs/researchinsights/2019/destination-bangladesh.pdf).

[24] FDI Statistics. DIPP.

(https://dipp.gov.in/publications/fdi-statistics).

[25] Box George EP and Gwilym Jenkins. (2015), Time Series Analysis: Forecasting and Control. Wiley Series.

[26] http://www.real-statistics.com/.

[27] https://www.solver.com/. 
International Journal of Engineering Applied Sciences and Technology, 2019

Vol. 4, Issue 8, ISSN No. 2455-2143, Pages 280-289

Published Online December 2019 in IJEAST (http://www.ijeast.com) 